\title{
THE CONVENTIONAL RESTRICTIVE AND THE MODERN LIBERAL INTERPRETATION OF SECTION 30 OF THE EVIDENCE ACT
}

\author{
Mohd. Akram Shair Mohamed ${ }^{*}$
}

\begin{abstract}
Section 30 of the Evidence Act allows the confession of an accused to be admitted against the co-accused. However, since it is a radical and dangerous departure from the rule that hearsay should not be admitted, the Indian and Malaysian Courts have not recognized such confession as falling within the definition of 'evidence'. It can only be used as a last resort and hence has been strictly construed throughout. But Singaporean Courts have now given it a liberal construction and elevated it to the status of a rule of evidence. The researcher's view is that this is dangerous and our courts should be wary of following Singaporean Courts' judicial thinking.
\end{abstract}

Keywords: Confession, Section 30 Evidence Act, strict interpretation, liberal interpretation.

Professor, Ahmad Ibrahim Kulliyyah of Laws, International Islamic University Malaysia. E-mail: akramm@iium.edu.my. I am grateful to the kind assistance rendered by Abd Shukor Ahmad, an Advocate \& Solicitor of High Court of Malaya for reading this Article in draft. 


\title{
TAFSIRAN TERHAD KONVENSIONAL DAN LIBERAL MODEN SEKSYEN 30 AKTA KETERANGAN
}

\begin{abstract}
ABSTRAK
Seksyen 30 Akta Keterangan membenarkan pengakuan salah seorang tertuduh diterima terhadap tertuduh bersama. Walaubagaimanapun, oleh kerana ia adalah satu penyimpangan yang radikal dan berbahaya daripada aturan bahawa dengar cakap sepatutnya tidak diterima, Mahkamah India dan Malaysia tidak mengiktiraf pengakuan salah sebegini sebagai terangkum dalam takrif 'keterangan'. Ia hanya boleh digunakan sebagai jalan terakhir dan oleh sebab itu telah sepanjang masa ditafsirkan dengan ketat. Tetapi Mahkamah Singapura sekarang telah memberikannya pentafsiran liberal dan meninggikannya ke status aturan keterangan. Pandangan penyelidik ialah tafsiran begini adalah berbahaya dan mahkamah kita sepatutnya berhati-hati mengikut pemikiran kehakiman Mahkamah Singapura.
\end{abstract}

Kata kunci: pengakuan salah, seksyen 30 Akta Keterangan, tafsiran ketat, tafsiran liberal.

\section{INTRODUCTION}

Section 30(1) Evidence Act reads:

“30(1) when more persons than one are being tried jointly for the same offence, and a confession made by one of those persons affecting himself and some other of those persons is proved, the Court may take into consideration the confession as against the other person as well as against the person who makes the confession." 
In Bhuboni Sahu v. King, ${ }^{1}$ Sir John Beaumont said at p. 260, that:

"This section was introduced for the first time in the Evidence Act 1872 and marks a departure from the Common Law of England.”

His Lordship noted "that the section applies to confessions and not to statements which do not admit the guilt of the confessing party. Section 30 seems to be based on the view that an admission by an accused person of his own guilt affords some sort of sanction in support of the truth of his confession against others as well as himself.” But, Sir John Beaumont observed that:

"a confession of a co-accused is obviously evidence of a very weak type. It does not indeed come within the definition of 'evidence' contained in section 3 of the Evidence Act." This is because "It is not required to be given on oath, nor in the presence of the accused, and it cannot be tested by cross-examination. It is a much weaker type of evidence than the evidence of an approver which is not subject to those infirmities. Section 30, however, provides that the court may take the confession into consideration and thereby, no doubt, makes it evidence on which the court may act: but the section does not say that the confession is to amount to proof (emphasis added). Clearly there must be other evidence. The confession is only one element in the consideration of all the facts proved in the case; it can be put into the scale and weighed with the other evidence. Their Lordships think that the view which has prevailed in most of the High courts in India that the confession of a coaccused can be used only in support of other evidence and cannot be made the foundation of a conviction is correct." 
In the Indian Supreme Court of Kashmira Singh v. State of M.P., ${ }^{2}$ Bose J after agreeing with what was observed by the Privy Council in Bhuboni Sahu, supra, said at p.160:

"The question is, in what way can it be used (a confession of a co-accused) in support of other evidence? Can it be used to fill in missing gaps? Can it be used to corroborate an accomplice, or as in the present case, a witness who, though not an accomplice, is placed in the same category regarding credibility because the Judge refuses to believe him except in so far as he is corroborated?"

In answer the learned judge said that the matter was put succinctly by Sir Lawrence Jenkins in Emperor v Lalit Mohan, ${ }^{3}$ where he said that such a confession can only be used to "lend assurance to other evidence against a co-accused," or put it in another way as Rei1ly $\mathrm{J}$ did in re Periyaswami Moopan: ${ }^{4}$

"The provision goes no further than this - where there is evidence against the co-accused, sufficient, if believed, to support his conviction, then the kind of confession described in s. 30 may be thrown into the scale as an additional reason for believing the evidence.

Translating these observations into concrete terms they come to this. The proper way to approach a case of this kind is, first to marshal the evidence against the accused excluding the confession altogether from consideration and see whether, if it is believed, a conviction could safely be based on it. If it is capable of belief independent of the confession, then of course it is not necessary to call the confession in aid. But cases may arise where the Judge is not prepared to act on the other evidence as it stands even though, if believed, it would be sufficient to sustain a conviction. In such an

$2 \quad$ AIR 1952159.

$3 \quad$ (1911) ILR 38 Cal 559 at 588.

$4 \quad$ (1930) Madras Law Journal 471; 129 Ind Cas 645. 
event the Judge may call in aid the confession and use it to lend assurance to the other evidence and thus fortify himself in believing what without the aid of the confession he would not be prepared to accept."

In Haricharan Kurmi v. State of Bihar ${ }^{5}$ the Indian Supreme Court was given the opportunity to relook at the status of the confession of co-accused under section 30. Gajendragadkar CJ at p. 1187 said that:

"The basis on which this provision is founded is that if a person makes a confession implicating himself, that may suggest that the maker of the confession is speaking the truth. Normally if a statement made by an accused person is found to be voluntary and it amounts to a confession in the sense that it implicates the maker, it is not likely that the maker would implicate himself untruly, and so, s. 30 provides that such a confession may be taken into consideration even against a co-accused who is being tried along with the maker of the confession. It is clear that a confession mentioned in s. 30 is not evidence under s. 3 of the Evidence Act, ... though such a confession may not be evidence as strictly defined by s. 3 of the Act it is an element which may be taken into consideration by the criminal court and in that sense, it may be described as evidence in a non-technical way. But it is significant that like other evidence which is produced before the court, it is not obligatory on the court to take the confession into account. When evidence as defined by the Act is produced before the court, it is the duty of the court to consider that evidence. What weight should be attached to such evidence, is a matter in the discretion of the court. But a court cannot say in respect of such evidence that it will just not take that evidence into account. Such an approach can, however be adopted by the court in dealing with a confession, because s. 30 
merely enables the court to take the confession into account.”

The learned CJ then concluded that "In dealing with a criminal case where the prosecution relies upon the confession of one accused person against another accused person, the proper approach to adopt is to consider the other evidence against such an accused person, and if the said evidence appears to be satisfactory and the court is inclined to hold that the said evidence may sustain the charge framed against the said accused person, the court turns to the confession with a view to assure itself that the conclusion which it is inclined to draw from the other evidence is right."

The learned CJ then supported his view by following the law that has been consistently followed for more than half a century, by Sir Lawrence Jenkins in Emperor v. Lalit Mohan Chukerburty, ${ }^{6}$ Reilly J in Periyaswami Moopan v. Emperor, ${ }^{7}$ Sir John Beaumont in Bhuboni Sahu v. The King, ${ }^{8}$ and Kashmira Singh v. MP. ${ }^{9}$

\section{RADICAL AND DANGEROUS DEPARTURE FROM THE ENGLISH COMMON LAW}

The Privy Council in Bhuboni Sahu v. King, ${ }^{10}$ observed that this section is a departure from the English common law, under which a co-accused's confession inculpating the accused is inadmissible against the accused because it is hearsay. The law before the Indian Evidence Act 1872 was that an accused person's confession was relevant only against himself and not against his fellow prisoners (see $R$ v. Kally Churn; ${ }^{11} R v$. Bussiruddin; ${ }^{12} R$ v. Durbaroo. ${ }^{13}$ ) The Indian Evidence Act 2 of 1955 and the Indian Criminal Procedure Codes of 1862 and 1872 did not have

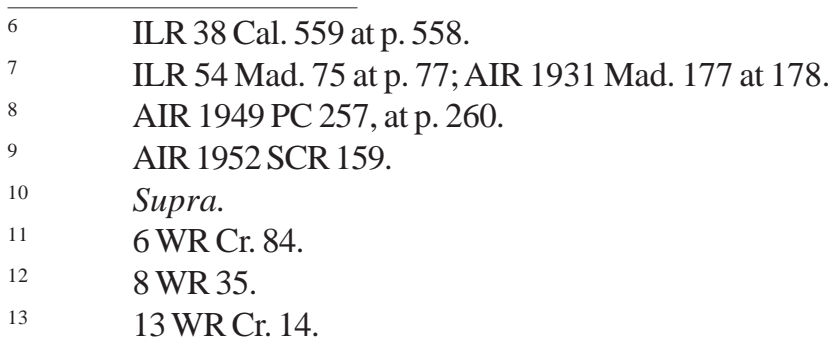


any provisions similar to section 30 of the Indian Evidence Act 1872. The consistently held judicial and academic view is that this section introduced a dangerous innovation liable to cause miscarriage of justice if not properly understood and correctly applied.

Eminent judges have consistently remarked adversely about the section. Glover $\mathrm{J}$ in $R$ v. Jaffer Ali ${ }^{14}$ considered this section as introducing a "rather dangerous element;" Phear $\mathrm{J}^{15}$ called it "dangerous material," while Coutt-Trotten $\mathrm{CJ}^{16}$ had "always thought that was a most unsatisfactory section and a needless tampering with the wholesome rule of the English law that a confession is only evidence against the person who makes it." And in Periyaswami Mooppan $v R,{ }^{17}$ Reilly $\mathrm{J}$ considered section 30 as "a very exceptional, indeed an extra-ordinary provision, by which something which is not evidence may be used against an accused person at his trial. Such a provision must be used with the greatest caution and with care to make sure that we do not stretch it one line beyond its necessary intention."

Markby ${ }^{18}$ noted that the provision is flatly in contradiction to the law of England where judges always take the greatest pain to prevent the statements of a prisoner affecting the case of a fellow prisoner; he said that he did not think that the judges in India "have looked with much favour on the section," Norton ${ }^{19}$ said that "This section introduces an innovation of a very serious character. However, because the section is already there - the judge cannot ignore it.” As Cunningham ${ }^{20}$ astutely observed:

"The judges are relieved from the attempt to perform an intellectual impossibility by a provision, that, when more persons than one are tried for an offence, and one makes a confession affecting himself and any other of the accused, the confession may be taken into consideration against such other person as well as against the person

$\begin{array}{ll}14 & \text { 19 WR Cr. } 57 . \\ 15 & \text { In } R \text { v Sadhu Mandal, 21 WR Cr. } 69 . \\ 16 & \text { In re Lilaram AIR 24 M 805. } \\ 17 & \text { AIR 1931 M 177. } \\ 18 & \text { W Markby Evidence, at p. } 28 . \\ 19 & \text { RF Norton, Evidence, at p. } 169 . \\ 20 & \text { Cunningham, Law of Evidence, Intro xxiv-XXv. }\end{array}$


making it. Such a confession is, of course, in the highest degree suspicious, it deserves ordinarily very little reliance; but nevertheless it is impossible for a single judge to ignore it, and under the Evidence Act, he need no longer pretend to do so.”

\section{STRICT CONSTRUCTION OF SECTION 30 BY INDIAN COURTS CONSISTENTLY}

Since the section introduces an entirely new and a dangerous element into the conduct of criminal trials, judges have construed it strictly and with the greatest caution and care to make sure that the section is not stretched beyond its necessary intention. As was lucidly enunciated in $R$ v. Chandra ${ }^{21}$ by Justice Jackson:

"The section does not provide as has been repeatedly pointed out by this court, that such confession is evidence; still less does it say that it may be the foundation of a case against the person implicated. The legislature very guardedly says that it may be taken into consideration ...the obvious intention of the legislature in so saying was that, when as against any such person there is evidence tending to his conviction, the truth or completeness of his evidence being the matter in question, the circumstance of such person being implicated by the confession of one of those who are being jointly tried with him should be taken into consideration as bearing upon the truth or sufficiency of such evidence."

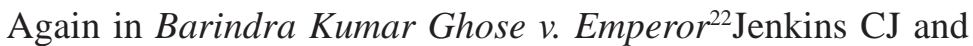
Carnduff J, said that the confession of an accused person is not evidence against a co-accused in the sense that conviction on that alone could be supported. It could only be taken "into consideration" under s. 30, that is to say, it can lend assurance to other evidence.

\begin{tabular}{ll}
\hline 21 & 24 WR Cr. 42. \\
22 & 14 CWN 114.
\end{tabular}


The confession of a co-accused does not come within the definition of evidence in section 3 , it is not given on oath, nor in the presence of the accused and cannot be tested by cross-examination. It is much weaker than the evidence of an accomplice. In fact the court has the discretion to exclude such a confession if it is so disposed. ${ }^{23}$

Thus the preponderance of Indian judicial authorities have construed section 30 strictly as that: The confession of a co-accused can be used only in support of other evidence and cannot be made the foundation of a conviction. With regard to how far and in what way the confession of an accused can be used in support of other evidence, it has been held that the proper way to approach it is first, to marshal the evidence against the accused, excluding the confession altogether, and see whether, if it is believed, a confession can be safely based on it. If it is capable of belief independently of the confession, then of course it is not necessary to call the confession in aid. But cases may arise where the judge is not prepared to act on the other evidence as it stands even though, if believed, it would be sufficient to sustain a conviction. In such an event the judge may call in aid the confession and use it to lend assurance to the other evidence and thus fortify himself in believing what without the aid of the confession he would not be prepared to accept Kashmira Singh v. State. ${ }^{24}$ The conviction of the accused must be based on other evidence. The confession of a co-accused can only be used to help to satisfy that the other evidence is true. ${ }^{25}$

The scope and effect of section 30 was succinctly placed in its proper perspective by the Indian Supreme Court in Hari-charan Kurni v. State of Bihar ${ }^{26}$ that:-

"It is clear that the confession mentioned in section 30 is not evidence under section 3 , which defines evidence as meaning and including:-

1. All statements which the Court permits or requires to be made before it by witnesses in

AIR 1952 SC 159.

Gunadhar Das v State AIR 1952 C 618.

AIR 1964 SC 1184. 
relation to matters of fact under inquiry: such statements are called oral evidence;

2. All documents produced for the inspection of the Court: such documents are called documentary evidence.

Technically construed, this definition will not apply to a confession, Part (1) of definition refers to oral statements which the court permits or requires to be made before it; and clearly a confession made by an accused person is not such a statement; it is not made or permitted to be made before the Court tries the criminal case.

Part (2) of the definition refers to documents produced for the inspection of the Courts; and a confession cannot be said to fall even under that part. Even though section 30 says that a confession may be taken into consideration not only against its maker but also against a co-accused person, that is to say, though such a confession may be evidence as strictly defined by section 3 , it is an element which may be taken into consideration by the criminal Court and in that sense it may be described as evidence in a non-technical way. But it is significant that like other evidence which is produced before the Court it is not obligatory on the Court to take the confession into account. When evidence as defined by the Act is produced before the Court it is the duty of the Court to consider that evidence. What weight should be attached to such evidence is a matter in the discretion of the Court. But a Court cannot say in respect of such evidence that it will just not take that evidence into account. Such an approach can, however be adopted by the Court in dealing with a confession, because section 30 merely enables the Court to take the confession into account. It has been consistently held that a confession cannot be treated as evidence which is substantive evidence against the co-accused person. In dealing with a criminal case where the prosecution relies upon the 
confession of one co-accused person against another accused person, the proper approach to adopt is to consider the other evidence against such an accused person, and if the said evidence appears to be satisfactory and the court is inclined to hold that the said evidence may sustain the charge framed against the said accused person, the court turns to the confession with a view to assure itself that the conclusion which it is inclined to draw from the other evidence is right.”

\section{THE MALAYSIAN ATTITUDE}

The Malaysian courts too have given a strict interpretation to section 30 as the Indian decisions. Two recent cases on the subject, P.P. v. Nordin bin Johan \& Anor ${ }^{27}$ and Dato Mokhtar Hashim \& Anor v. P.P. ${ }^{28}$ where the latter will be remembered as a cause celebre in the annals of Malaysian legal history, clearly reflect the Malaysian view.

Nordin's case can be best understood against the backdrop of the facts of Dato Mokhtar Hashim's case itself. The two respondents Nordin bin Johan and Aziz Abdullah together with Datuk Mokhtar Hashim and Rahmat Satiman were jointly charged with the murder of Datuk Mohd Taha bin Taib, on April 1982, at Kampung Seri Asahan, Gemencih in Tampin, Negeri Sembilan.

Save for Rahmat Satiman's confession (which the learned trial judge had ruled to be admissible after a sensational trial within a trial), implicating Nordin and Aziz in the offence charged, the only other evidence linking the two respondents with the murder was that of one Atun, a prosecution witness, who had testified that he saw both Nordin and Aziz one midnight with the company of Datuk Mokhtar Hashim and others. Besides this identification evidence of Atun, the only other evidence against Nordin consisted of the statement of Nordin's visit to the Deputy C.P.O. Negeri Sembilan to inform him of the probable identity of a night caller to the late deceased's house, and Nordin's attendance at the deceased's funeral without a beard. 
Apart from Rahmat Satiman's confession, the learned trial Judge held that this evidence against both the respondents was insufficient to sustain the charge against them. Could the confession implicating both the respondents be considered?

In answering this question, Hashim Yeop Sani J. after citing section 30 of the Evidence Act referred to a trilogy of strong Malaysian cases namely Herchun Singh \& Ors. v. P.P.;29 Yap Chai Chai \& Ors v. P.P., ${ }^{30}$ and Yusof \& Anor v. P.P., ${ }^{31}$ and the leading Privy Council decision in Bhuboni Sahu v. King and one Supreme Court decision of India, Kashmira Singh v. State of M.P., and said (at pp. 268-269):

"It is clear from a long line of authorities that a confession of a co-accused is only an element in the consideration of other evidence which evidence must be sufficient to support a conviction."

In Gunadhar Das v. State ${ }^{32}$ it was stated similarly:

"In short the conviction must be based on the other evidence. The confession can only be used to help to satisfy a court that other evidence is true."

H.T. Ong CJ in Herchun Singh clarified the position clearly (at p. 210) where he said:

In our judgement, however, the proper interpretation of section 30 is that of Bose J in Kashmira Singh, as follows:

"The proper way to approach a case of this kind is, first to marshal the evidence against the accused excluding the confession altogether from consideration and see whether 'if it is believed,' a conviction could safely be based on it. If it is capable of belief independently of the

\begin{tabular}{ll}
\hline 29 & [1969] 2 MLJ 209. \\
30 & [1973] 1 MLJ 219. \\
31 & [1956] MLJ 47 at p. 48. \\
32 & AIR 1952 Cal. 618.
\end{tabular}


confession, then of course it is not necessary to call the confession in aid. But cases may arise where the Judge is not prepared to act on the other evidence as it stands, even though, 'if believed,' it would be sufficient to sustain a conviction. In such an event the judge may call in aid the confession and use it to lend assurance to the other evidence and thus fortify himself in believing what without the aid of the confession he would not be prepared to accept.”

The principle in Herchun Singh was reiterated by the same learned Chief Justice in another Federal Court case of Yap Chai Chai \& Anor v. PP. Stated simply, the principle is as follows. It would be proper for the trial judge to take the confession of one accused into consideration against the other accused to lend assurance to other evidence against the other co-accused. In my view, the operative words in the judgment in Kashmira Singh are the words 'to lend assurance' which means that there must be other positive evidence against a coaccused before the confession of an accused can be called in aid to lend assurance to it. This principle is carried in many Indian decisions and I think it is a logical principle. If (P101) is to be permitted in law to be used against other persons without any more positive evidence against such persons, then not only should the four accused be in the dock now but also Abdullah Ambik (PW30) and Ma'dan who according to (P101) were at the scene of the crime and participated in the execution of the prearranged plan.

As to why the law is strict on the application of a confession of an accused person as against a co-accused is not difficult to appreciate because it is based on a very sound principle. Since a confession is neither required to be given on oath nor to be made in the presence of the other co-accused whom it implicates, it is therefore not wrong to describe it as a very weak type of evidence which should only be used in support of other positive evidence. This, in my opinion, is the intention of section 30 of the Evidence Act when it used the words 'may take into consideration.'

I am merely echoing the view of the Privy Council in Bhuboni Sahu v. R. Sir John Beaumont observed that 'a confession of a coaccused is obviously evidence of a very weak type ... The confession is only one element in the consideration of all the facts proved in 
the case; it can be put into the scale and weighed with the other evidence.'

The result is therefore that in dealing with the confession of Rahmat Satiman as against the other accused the Court should not start with the confession but should begin with other evidence adduced by the prosecution and after it has formed its opinion with regard to the quality and effect of the evidence then it is permissible to turn to the confession in order to receive assurance as to the conclusion of guilt of the coaccused.

Let me now deal with the evidence against the co-accused, first, with regard to Nordin bin Johan, the second accused and Aziz Abdullah, the fourth accused. Apart from the confession of Rahmat Satiman the only evidence which purports to connect them with the death of Dato Taha (PW18) at about midnight on April 13, 1982 together with three others, namely Dato Mokhtar, Aziz Tumpuk and Abdullah Ambik, is that they were seen near a white car in Gan Kee Estate, 31/2 miles away from the scene of the crime and about $1 \frac{1}{2}$ hours before the time of the murder. Abdullah Ambik turned hostile to the prosecution and Aziz Tumpuk is dead.

In a somewhat similar vein Matthew C.J. said in the judgment of the Court of Appeal in Yusoff \& Anor. v. P.P.:

"Quite apart from this, even accepting the confession of the $2^{\text {nd }}$ appellant as being both voluntary and true, there is the question whether the confession was sufficient to establish the guilt of the $2^{\text {nd }}$ appellant. Section 30 of the Evidence Ordinance reads:

When more persons than one are being tried jointly for the same offence, and a confession made by one of such persons affecting himself and some other of such persons is proved, the Court may take into consideration such confession as against such other person as well as against the person who makes such confession.

The effect of the words 'may take into consideration' is well set out in Woodroffe \& Ameer Ali's Law of Evidence, 9th edition, at pp. 312 \& 313, as follows: 
These words do not mean that the confession is to have the force of sworn evidence, but such a confession is nevertheless evidence in the sense that it is a matter which the Court, before whom it is made, may take into consideration in order to determine whether the issue of guilt is proved or not. The wording, however, of this section (which is an exception) shows that such a confession is merely to be an element in the consideration of all facts of the case; while allowing it to be so considered, it does not do away with the necessity of other evidence.”

His Lordship accordingly held that except for some identification evidence, there was no evidence against the co-accused.

On appeal to the Federal Court, by the Public Prosecutor, - sub nom. P.P. v. Nordin bin Johan ${ }^{33}$ that the trial Judge had failed to give due weight to the statement of the co-accused, Raja Azlan Shah L.P. (as his Highness then was) (at p. 222) observed:

"This leaves the question of the application of the provisions of section 30 of the Evidence Act 1950 in relation to the 2 respondents as a result of the statement made by Rahmat Satiman, the $3^{\text {rd }}$ accused in these proceedings, which was admitted and accepted and which clearly implicates the 2 respondents. Section 30 provides that this statement may be taken into consideration against the 2 respondents but on the decided authorities the prerequisite to this is that there must be some cogent evidence against them quite apart from the statement of the $3^{\text {rd }}$ accused. The nature of this evidence which would be extraneous to the confession of a co-accused and its qualitative and probative value in relation to the charge must, ex necessitate rei, be a factual matter in the context and circumstances of the particular case. Having considered the evidence against the 2 respondents, which is fairly voluminous and lengthy, the learned Judge came to the conclusion that, it did not, in relation to them have 
any real probative value to the charge and even taken as a whole did not take the prosecution case anywhere for the purpose of proving common intention under section 34 of the Penal Code. The learned trial judge had opportunities which are denied to us, of considering, whether it would be safe to draw the inference that the 2 respondents were present at the scene of the crime and participated in the commission of the offence.

His Lordship then asked:

"Does the totality of the evidence against the second accused and the fourth accused excluding the confession (P101) lead the court to the irresistible inference that they were present at the scene of the crime and participated in the commission of the offence? I am afraid I am unable to honestly give an affirmative answer to this question.

On a considered view of the case we find no justification to warrant interference with the learned trial Judge's conclusion in this matter. We are satisfied that the evidence against the 2 respondents, apart from the $3^{\text {rd }}$ accused's confession, was not sufficient to satisfy the requirements of the charge against them and that calling on their defense, the authorities would not only go beyond taking into consideration the $3^{\text {rd }}$ accused's statement but be tantamount to virtually relying on it to an extent that would not be permissible for the purposes of section 30 of the Evidence Act. We would accordingly in the circumstances dismiss this appeal by the Public Prosecutor."

In Yusoff \& Anor v. P.P.,$^{34}$ the appellants were convicted for the murder of an unknown Malay lady. The prosecution case rested almost entirely on a confession made by the second accused to a magistrate laying the entire blame for the killing on the first accused. When brought before the 
magistrate, the second accused told the magistrate that he decided to tell the truth as his wife would be put in trouble by being detained. The statement in the confession as to the manner in which deceased met her death was not supported by medical evidence.

On appeal against the admissibility of the confession implicating the co-accused, the appeal court held that as there was a suggestion that there was a motive other than the desire to tell the whole truth in the second appellant's mind when he made his confession and as it appeared that certain statements in the confession could not be true, it was necessary for the trial Judge to examine the question whether the confession was voluntary and its contents true.

Even accepting the confession as voluntary and true, it alone, was insufficient to ground the first appellant's conviction.

In P.P. v. Lai Pong Yuen \& Ors., ${ }^{35}$ although the three accused were jointly tried, they were not tried for the same offence. Hence a confession of one of the co-accused implicating one of the other accused was held inadmissible under section 30 of the Evidence Ordinance.

The facts were that somewhere in November 1964, the $3^{\text {rd }}$ accused had erected two unauthorized buildings on his land within the Seremban Town Council, and later received notice from the Council to demolish them. In February 1965 he met the $2^{\text {nd }}$ accused, the Deputy President of the Council about the notices and gave him a cheque of $\$ 200.00$ as deposit for the Council for 'things to be in order.'

However he still received a demolition notice after this. He therefore met the President of the Council, the $1^{\text {st }}$ accused, who after inspecting the building asked and received from him a further deposit of $\$ 2500$, by an undated cheque endorsed on the back. After this the Council adopted its policy of summoning the owners of unauthorized structures instead of implementing the demolition orders.

A police investigation later led to a joint trial of the three accused at the Sessions Court charging:

(a) The $1^{\text {st }}$ accused as President of the council for receiving $\$ 2,500$ as gratification for preventing the performance of an official act contrary to the Prevention of Corruption Act 1961, alternatively for bribery under the Penal Code, 
(b) the $2^{\text {nd }}$ accused for receiving $\$ 200$ contrary to Prevention of Corruption Act 1961 and under the Penal Code; and

(c) the $3^{\text {rd }}$ accused with two offences of offering inducement to prevent performance of an official act under the Prevention of Corruption Act 1961.

The Prosecution case consisted of:

(1) Evidence of one Chin, former Town Councilor who, testified about the $3^{\text {rd }}$ accused's meetings and payment of the said sums to the two co-accused to see that 'things will be in order', and a letter sent by the $3^{\text {rd }}$ accused's solicitor to the Town Council informing it of the two payments made to the $1^{\text {st }}$ and $2^{\text {nd }}$ accused, deposit for the temporary buildings on the $3^{\text {rd }}$ accused's land and an assurance given that no further action would be taken about the two buildings.

(2) The testimony of the Town Council Secretary that on receipt of the $3^{\text {rd }}$ accused's solicitor's letter he saw both the $1^{\text {st }}$ and the $2^{\text {nd }}$ accused about it, both of whom denied their contents.

(3) One R - who testified that his advice to the Council that the buildings be demolished was not heeded to be the $1^{\text {st }}$ accused.

(4) Evidence of the document examiner, that the cheque for $\$ 2,500$ bore the $3^{\text {rd }}$ accused's signature and endorsement at the back, though there was nothing to connect it to the $1^{\text {st }}$ accused and that the cheque for $\$ 200$ was drawn by the $3^{\text {rd }}$ accused and endorsed by the $2^{\text {nd }}$ accused.

(5) The Council's Health Inspector who testified that he found two unauthorized sheds on the $3^{\text {rd }}$ accused's property.

(6) Two cautioned statements taken from the $3^{\text {rd }}$ accused, which were not only self-inculpatory but also implicated the $2^{\text {nd }}$ accused, (that said that $\$ 2,500$ was given as a loan to the $1^{\text {st }}$ accused). 
The President of the Sessions Court acquitted and discharged the three accused without calling for their defense.

The Public Prosecutor appealed against the acquittal contending:

a. Against the $1^{\text {st }}$ respondent that there was evidence that he had accepted \$2,500 corruptly from the following circumstances. The date in the cheque given to him was left blank. The $3^{\text {rd }}$ respondent was served with notices to demolish his sheds. This despite the fact that the Council had decided on $13^{\text {th }}$ May 1965 (i.e. after the notices) to institute Court proceedings instead.

b. Against the $2^{\text {nd }}$ respondent, that his signature on the back of the cheque (for \$200) together with the Council's change in policy regarding unauthorized buildings, and the cautioned statement was sufficient to establish a prima facie case against him.

Ismail J. Khan held that:

Concerning the $1^{\text {st }}$ respondent there was no evidence to indicate of him having received \$2,500 to warrant the introduction of evidence to show that it was corruptly received or to rebut the defense that it was for an innocent purpose.

Respecting the $2^{\text {nd }}$ respondent, though the Session Court President had admitted the cautioned statement, he attached no weight to it. Even assuming that some weight could be given to it, its use regarding the $2^{\text {nd }}$ respondent would depend on a strict adherence to the provisions of section 30 of the Evidence Ordinance. Without the cautioned statement the case against the second respondent would rest only on the evidence:

(1) of the cheque which he received

(2) of the demolition notices concerning the $3^{\text {rd }}$ respondent's sheds

(3) of the Town Council's decision to institute proceedings against the owners instead of demolishing the buildings. 
In his Lordship's view such evidence by itself was insufficient to support a conviction. There was no evidence of how the $2^{\text {nd }}$ respondent endorsed the cheque or if it was given to him, of the circumstances in which it was done or for what purpose. It was necessary to use the cautioned statement to fill the gaps in the prosecution case which was not open to him.

Ismail Khan C.J. then adverted to a long line of authorities that a confession of a co-accused is only an element in the consideration of other evidence which must be sufficient to support a conviction. He referred to Bhuboni Sahu v. The King ${ }^{36}$ where Sir John Beaumont said at p.260:

"The confession is only one element in the consideration of all the facts proved in the case, it can be put into the scale and weighed with other evidence. Their Lordships think that the view which has prevailed in most of the High Courts in India, namely that the confession of a coaccused can be used only in support of other evidence and cannot be made the foundation of a conviction is correct."

He also found a further ground for excluding the cautioned statement in the case of the $2^{\text {nd }}$ respondent.

An essential requirement of section 30 is the joint trial of the respondents for the same offence. Same offence means identical offences. In the instant case all the three respondents were charged for offences under section 9(ii) of Prevention of Corruption Act.

The offences alleged against the $1^{\text {st }}$ and $2^{\text {nd }}$ respondents were on different dates. The cautioned statement implicated only the $2^{\text {nd }}$ respondent. Further there were alterative charges under the Penal Code against the first two respondents. Hence there was no joint trial for the same offence for the purpose of section 30 of the Evidence Ordinance.

Respecting the confession of the $3^{\text {rd }}$ respondent, which the Public Prosecutor was urging the Court to accept, the learned judge also held that considering the $3^{\text {rd }}$ respondent's conduct and the discrepancies in

$36 \quad$ AIR 1949 PC 257. 
both his cautioned statements, the lower court was justified in not attaching any value to his confession.

Therefore apart from the confession there was no substantial evidence against him either. The appeal was accordingly dismissed.

In Herchun Singh \& Ors. v. P.P, ${ }^{37}$ the Federal Court was given the opportunity of considering the application of section 30 of the Evidence Act.

The three appellants were among the five persons who were charged with gang robbery. Ramasamy, one of the co-accused, had made a statement confessing to the offence and implicating his co-accused. The three appellants together with Ramasamy were convicted. The appellants appealed, one of their grounds of appeal being that Ramasamy's confession, which implicated them, was not a confession and so should not have been taken into consideration against them, in the absence of other evidence implicating them and each of them.

Ong Hock Thye C.J. (at pp. 209-210) however confirmed the trial Judge's ruling that Ramasamy's statement was a confession, because it told of a robbery and his own participation in it.

By stating that he was under coercion he did not negate the offence to which Ramasamy confessed. As the trial Judge said, though Ramasamy may not have been the villain he did participate in the robbery. Therefore respecting the exculpatory statements the Judge interpreted them as in no way negating the facts which constituted the offence. This in the Federal Court's view was not inconsistent with Lord Atkin's judgment in Pakala Narayana Swami v. King-Emperor ${ }^{38}$ that "no statement that contains self-exculpatory matter can amount to a confession if the exculpatory statement is of some fact which if true would negate the offence alleged to have been committed." Ramasamy's allegation of coercion even if true, which was held not to be so, was no defense under section 94 of the Penal Code. The offence of robbery in the instant case was not negated by the confessional statement or Ramasamy's participation therein, including his receipt of part of the proceeds of the crime. Therefore Ramasamy's statement was a confession that, while making it, Ramasamy did not magnify his comrades' guilt, to trade his

$38 \quad$ [1939] MLJ 48. 
own liberty for theirs. His own guilt or innocence did not bear on their being answerable for the joint offence.

On this view of the confession it followed that section 30 of the Evidence Ordinance properly applied, to enable the confession to be considered as against the other persons jointly tried for the same offence and were affected thereby. The learned C.J. made a qualified acceptance of Ismail Khan J's judgment in Public Prosecutor v. Lai Pong Yuen ${ }^{39}$ where he followed Bhuboni Sahu v. The King ${ }^{40}$ and Kashmira Singh v. State of Madhya Pradesh. ${ }^{41}$

In Lai Pong's case Ismail J. had said that a confession of a coaccused was only an element in the consideration of other evidence which evidence must be sufficient to support a conviction.

The Federal Court held the proper interpretation of section 30 is to be found in the judgment of Bose J. in Kashmira Singh's case, ${ }^{42}$ that "The proper way to approach a case of this kind, is first to marshal the evidence against the accused excluding the confession altogether from consideration and see whether 'if it is believed,' a conviction could safely be based on it. If it is capable of belief independently of the confession, then it is not necessary to call the confession in aid. But cases may arise where the Judge is not prepared to act on the other evidence as it stands even though, if believed, it would be sufficient to sustain a conviction. In such event the judge may call in aid the confession and use it to lend assurance to the other evidence and thus fortify himself in believing what without the aid of the confession he would not be prepared to accept."

Ong Hock Thye C.J. said that in the instant case the trial Judge quoting with approval Bose J. in Kashmira Singh had said:

"As regards the first and third accused (the first and second appellant), I first took into consideration the evidence against each of them, independently of the confession of the fifth accused. But I was not prepared to act on this other evidence as it stood so as to convict

\begin{tabular}{ll}
\hline 39 & [1968] 1 MLJ 12 at p. 14. \\
40 & AIR 1949 PC 257. \\
41 & AIR 1952 SC 159. \\
42 & Ibid.
\end{tabular}


them. Against each of them, therefore, I called in aid the confession and used it to lend assurance to the other evidence and thus fortify myself in believing the two accused to be guilty. In other words, I threw the confession into the scale as an additional reason for believing the other evidence that there was against each of them.”

He therefore held that the trial Judge had rightly taken into consideration Ramasamy's confession, because there was sufficient independent evidence against the second appellant, fortifying the naming of the second appellant in the confession to support the conviction.

Herchun Singh's case was applied by the Federal Court in Yap Chai Chai \& Anor. v. P.P. ${ }^{43}$ The two appellants were charged jointly with one another still at large for murdering a goldsmith in the course of an attempted armed robbery. They were convicted. Among the grounds of appeal were:-

(a) that a retracted confession of the second appellant which it was alleged was made as a result of police pressure and inducement, should not have been admitted,

(b) that the statement in question was self-exculpatory and so not being a confession was wrongly admitted,

(c) the second appellant's confession should not have been used or considered against the first appellant of common intention.

Ong C.J. rejected these submissions stating that, concerning (a) above, the confessional statement was rightly admitted, because any inducement or coercion if at all there was, had been clearly dissipated when the magistrate to whom the statement was later made, had carefully and thoroughly questioned the second appellant to ensure that it was made voluntarily. The magistrate when recording it was quite clearly satisfied of its voluntariness. 
On submission (b) the learned C.J. did not agree that the statement was wrongly admitted. The statement was a clear admission of participation in the attempted robbery and consequently it was a statement having reference to the charge against him, which was a murder committed in the course of a robbery wherein there was evidence of common intention to use deadly weapons.

Ong C.J. again rejected submission (c) because the Federal Court in Herchun Singh's case had clearly laid down that a confession of a coaccused can be taken into consideration against the other to lend assurance to the other evidence against him in believing the accused to be guilty. In the instant case the first appellant's involvement in the robbery was admitted by him in his own statement from the dock. On this point corroboration by the second appellant was superfluous. As to proof of common intention their joint involvement in the carefully planned robbery must have led irresistibly, from the fact of two of the three being armed with lethal weapons, to the inference of common intention to use those weapons when needed. He accordingly dismissed the appeal.

In the recent Court of Appeal case of Juraimi Husin v. P.P., ${ }^{44}$ Gopal Sri Ram JCA in his own inimitable way said of section 30 of the Act as follows:

"We now turn to the complaint by counsel for the second and third accused that the learned judge misdirected the jury on the application of s.30 of the Evidence Act 1950.

The way in which the section must be applied has been fairly worked out in the decided cases. The evidence against an accused must be first marshaled putting aside the confession of the co-accused. If the court is prepared to convict on the other evidence, it may pray in aid the co-accused's confession to lend assurance to the conclusion of guilt already arrived at. As observed by Raja Azlan Shah LP in Public Prosecutor v. Nordin bin Johan \& Anor. ${ }^{45}$

Section 30 provides that this statement may be taken into consideration against the 2 respondents but on

\begin{tabular}{ll}
\hline 44 & {$[1998] 2$ CLJ 383. } \\
45 & {$[1983] 2$ MLJ 221 at 222.}
\end{tabular}


the decided authorities the prerequisite to this is that there must be some cogent evidence against them quite apart from the statement of the $3^{\text {rd }}$ accused. The nature of this evidence which would be extraneous to the confession of a co-accused and its qualitative and probative value in relation to the charge must ex necessitate rei be a factual matter in the context and circumstances of the particular case.

In the instant case, the learned judge's summingup when read as a whole makes it abundantly clear that the jury were instructed in clear terms that they should consider the evidence apart from the confession. At one stage of the summing-up, the learned trial judge pointed out that the prosecution had adduced sufficient evidence to establish the charge, after putting aside the confessions of the first and third accused. He went on to say that the jury was at liberty to disregard his views on the evidence if they were not in agreement with the views expressed. He also warned the jury on the danger of acting on the confession of a co-accused. We are satisfied that there was in the circumstances of the present case a proper direction on s. 30. We accordingly find no merit in this ground of complaint.”

The local authorities also agree with Indian cases that a confession of an accused implicating the co-accused is not evidence within the meaning of section 3 of the Evidence Act.

This was clearly recognized and accepted by the Court of Appeal by Matthew C.J. in Yusuff \& Anor v. P.P., later approved in Herchun Singh, Yap Chai Chai and Dato Mokhtar Hashim. All these cases approved Bhuboni Sahu v. $R^{46}$ where Sir John Beaumont said that:

" a confession of a co-accused is obviously a very weak type of evidence. The learned Lord of the Privy Council said (at p. 155) that "a confession of an accused is obviously evidence of a very weak type. It 
does not indeed come within the definition of 'evidence' contained in section 3 of the Evidence Act. It is not required to be given on oath, nor in the presence of the accused, and it cannot be tested by cross-examination. It is a much weaker type of evidence than the evidence of an approver, which is not subject to any of those infirmities.

Section 30, however, provides that the court may take the confession into consideration and thereby, no doubt makes it evidence on which the court may act; but the section does not say that the confession is to amount to proof."

Similar sentiments were expressed locally by Murray-Aynsley C.J. in the old case of Koh Ah Chua \& Others v. P.P., ${ }^{47}$ where the appellants and three others were convicted of robbery. The evidence upon which the appellant was convicted was the uncorroborated confession of a co-accused made to a Magistrate and duly proved at the trial.

Murray Aynsley C.J., quashing the conviction on the ground that there was insufficient evidence to sustain the appellants' conviction said that:

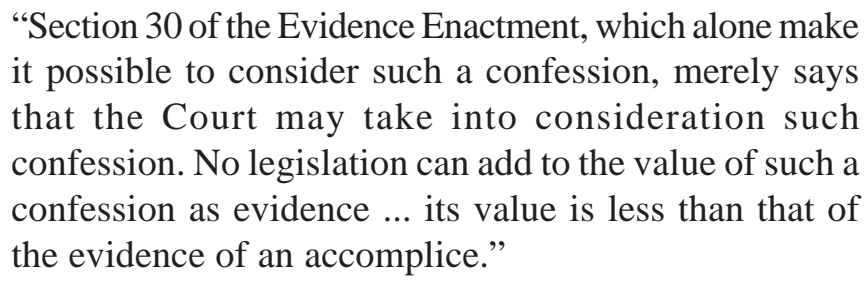

The reasons he gave for this is because firstly it was made in the absence of the co-accused, secondly it was not made on oath and thirdly it was not subject to cross-examination, and finally in such cases the person making the confession attributes the chief blame on others. And such evidence is not ordinarily sufficient without corroboration. 235. 
Finally recently in Chan Ming Cheng v. P.P. ${ }^{48}$ the Court of Appeal through Gopal Sri Ram JCA said at p. 81 "while an accused may not be convicted on the confession of a co-accused, an accused may be convicted on his own confession.”

\section{LIBERAL INTERPRETATION OF SECTION 30 BY SINGAPORE COURTS}

Whilst the Indian courts, including the Privy Council when asked to interpret have consistently given a strict interpretation to section 30, and followed likewise by the Malaysian courts, Singapore has recently chosen to depart from this traditional approach and have elected to follow a liberal path.

This liberal interpretation of section 30 of the Evidence Act is reflected in two well-reasoned judgments of the Singapore Criminal Court of Appeal, both judgments delivered in the lucidly written words of Yong Pung How CJ. The two cases are Abdul Rashid \& Anor v. P.P., ${ }^{49}$ and Chin Seow Noi \& Ors. v. P.P. ${ }^{50}$

The common thread that runs through both the learned CJ's judgments in giving section 30 of the Evidence Act a wider interpretation are:

(1) The Indian authorities on the definition of a confession are not helpful due to the different wording in the Singapore counterpart legislations which includes the words 'suggesting the inference that he committed the offence'. Unlike in India, for a statement to amount to a confession it need not be of a plenary or unqualified nature and can also be of a non-plenary nature, so long as the statement connects the accused in some way with the offence.

$\begin{array}{ll}48 & \text { [2002] 4 CLJ 77. } \\ 49 & \text { [1994]1 SLR 119. } \\ 50 & {[1994] 1 \text { SLR 135. }}\end{array}$


(2) The conventional narrow construction accorded to section 30 by established authorities requiring a co-accused's confession to be first isolated from the rest of the evidence against an accused until the other evidence against the accused is on its own sufficient to establish the ingredients of the offence, can no longer be followed.

(3) Substantial differences between the evidential provisions in India and Singapore as well as the different local conditions compel a departure from the narrow approach espoused by the earlier cases. The Indian courts accord a very restrictive treatment to out of court statements and in particular to confessions of accused persons, whereas Singapore courts adopt a much wider approach in that as much relevant evidence as possible should be put before a court in order for it to assess its value. These reasons are found in Abdul Rashid v. PP. ${ }^{51}$

Two further differences of the Indian Evidence Act and the Singapore counterpart were also highlighted in Chin Seow Noi v. PP by Yong Pung How CJ at pp. 155-158.

"As we have pointed out earlier, there exist crucial differences between the Indian law of evidence and our law of evidence which are of great relevance to a proper construction of s. 30 . What must be recognized about the Indian authorities is that they were decided strictly within the confines of the Indian Evidence Act. It is not enough, therefore, to say that s. 30 in their Act is word for word the same as s. 30 in our Evidence Act. The Indian Evidence Act of 1872 is a different creature altogether from our Evidence Act, many of its provisions influenced by the socio-political considerations as well as the legal 
jurisprudence prevailing in India at the time the Act was drafted. The Indian courts, in interpreting their s. 30, were conscious at all times of the other provisions of their Evidence Act and other provisions in related legislation impinging upon their 1aw of evidence. Consequently, the construction they gave to their s. 30 was shaped by the perceived need to ensure the consistency of that section with the whole body of the Indian law of evidence."

One of the most important factors influencing the Indian courts was the need for corroboration of an accomplice's testimony, a need stemming from the provisions of s. 133 and of illustration (B) to s. 114 of the Indian Evidence Act. Section 133 provides that:

An accomplice shall be a competent witness against an accused person; and a conviction is not illegal merely because it proceeds upon the uncorroborated testimony of an accomplice.

Illustration (B) to s. 114 provides, however, that:

The court may presume that an accomplice is unworthy of credit unless he is corroborated in material particulars.

In Bhuboni Sahu, Sir John Beaumont, speaking of the need for corroboration of an accomplice's evidence, stated at p.26l:

The danger of acting upon accomplice evidence is not merely that the accomplice is on his own admission a man of bad character who took part in the offence and afterwards to save himself betrayed his former associates, and who has placed himself in a position in which he can hardly fail to have a strong bias in favour of the prosecution; the real danger is that he is telling a story which in its general outline is true, and it is easy for him to work into the story matter which is untrue ... This tendency to include the innocent with the guilty is peculiarly prevalent in India, as judges have noted on innumerable occasions, and it is very difficult for the court to guard against the danger. [Emphasis added]. 
Bhuboni Sahu and similar Indian cases were thus, to a great extent, concerned with the evidentiary value of a co-accused's confession in corroborating an accused person's testimony. In Bhuboni Sahu, the court's remarks to the effect that a co-accused's confession was obviously 'evidence of a very weak type' were apparently made in response to the argument by the Crown in that case that the confession of the appellant's co-accused, Trinath, constituted sufficient corroboration of the evidence of the appellant's accomplice (the 'approver') Kalia Behara: see, in particular p. 260 of the judgment, at paras B-9.

In Singapore, although we have s. 116 illustration (b), which is identical with illustration (B) of s. 114, the situation established by s. 135 of our Act is in direct contrast to that created by s. 114 of the Indian Evidence Act. Section 135 provides that:

An accomplice shall be a competent witness against an accused person; and any rule of law or practice whereby at a trial it is obligatory for the court to warn itself about convicting the accused on the uncorroborated testimony of an accomplice is hereby abrogated.

We note also that the definition given to 'evidence' in s. 3 of the Indian Evidence Act was clearly intended to be an exhaustive one and that the confession of a co-accused cannot be fitted within this rather narrow definition. Section 3 states:

'Evidence' means and includes:

(1) all statements which the court permits or requires to be made before it by witnesses, in relation to matters of fact under inquiry; such statements are called oral evidence;

(2) all documents including electronic records produced for the inspection of the Court; such documents are called documentary evidence. [Emphasis added]. 
The phrase 'means and includes' makes the definition both explanatory and exhaustive: see Dilworth \& Ors. v. Commissioner of Stamps. ${ }^{52}$ This is in marked contrast to s. 3 in our Evidence Act which states: 'Evidence' includes:

(1) all statements which the court permits or requires to be made before it by witnesses, in relation to matters of fact under inquiry; such statements are called oral evidence;

(2) all documents produced for the inspection of the Court; such documents are called documentary evidence. [Emphasis added].

The use of the single word 'includes' in our s. 3 is clearly intended to make the definition of 'evidence' in our Evidence Act an extensive one: Dilworth \& Ors $v$. Commissioner of Stamps, and also Corporation of Portsmouth v. Smith \& Ors. Within the context of our Evidence Act, 'evidence' may thus be given not just the narrow statutory meaning explicitly spelt out in s. 3 itself but also, where applicable, its ordinary, popular and natural meaning. In other words, the scope of admissible evidence as provided for in our Evidence Act is considerably broader than that provided for in the Indian equivalent. In contrast to the situation in India, in Singapore confessions by co-accused persons may be included in the whole body of what is understood to be 'evidence' within the parameters set by our Evidence Act. This is another reason why this court arrived at the view that the interpretation of s. 30 established by such cases as Bhuboni Sahu and Kashmira Singh could no longer be simplistically accepted as being the authoritative interpretation of s. 30 as it stands within our Evidence Act. The judgments in these Indian cases are replete 
with statements to the effect that s. 30 should be construed narrowly because the confession of a coaccused cannot be fitted within the restricted definition of evidence given in s. 3 of the Indian Evidence Act. In Haricharan Kurmi, for example, Gajendragadkar CJ stated at various parts of his judgment:

It is clear that the confession mentioned in s. 30 is not evidence under s. 3 of the Act (p. 1187) ... It is not obligatory on the court to take the confession into account. When evidence as defined by the Act is produced before the court, it is the duty of the court to consider that evidence. What weight should be attached to such evidence is a matter in the discretion of the court. But a court cannot say in respect of such evidence that it will just not take that evidence into account. Such an approach can, however, be adopted by the court in dealing with a confession because s. 30 merely enables the court to take the confession into account (p. 1 188)...

The testimony of the accomplice is evidence under s. 3 of the Act and has to be dealt with as such. It is no doubt evidence of a tainted character and as such, is very weak; but, nevertheless, it is evidence and may be acted upon subject to the requirement, which has now become virtually a part of the law, that it is corroborated in material particulars.

The statements contained in the confessions of the co-accused persons stand on a different footing. In cases where such confessions are relied upon by the prosecution against an accused person, the court cannot begin with the examination of the said statements. The stage to consider the said confessional statements arrives only after the other evidence is considered and found to be satisfactory (at p. 1 189). [Emphasis added]

Further evidence of the rather more limited scope of admissible evidence provided for by the Indian Evidence Act, as compared to that provided for by our Evidence Act, may be seen in the treatment of confessions in the Indian Evidence Act. Section 25 of the Indian Act provides that 'no confession made to a 
police officer shall be proved as against a person accused of any offence.' Section 26 provides that no confession made by any person whilst in police custody, shall be proved against such person, unless it was in the presence of a magistrate. This is backed up by certain provisions in the Indian Criminal Procedure Code, notably s. 162(1) of that Code, which provides:

No statement made by any person to a police officer in the course of an investigation under this Chapter shall, if reduced into writing, be signed by the person making it; nor shall any such statement or any record thereof whether in a police diary or otherwise, or any part of such statement or record, be used for any purpose (save as hereinafter provided) at any inquiry or trial in respect of any offence under investigation at the time when such statement was made:

Provided that when any witness is called for the prosecution in such inquiry or trial whose statement has been reduced into writing as aforesaid, any part of his statement, if duly proved, may be used by the accused, and with the permission of the court, by the prosecution, to contradict such witness in the manner provided by section 145 of the Indian Evidence Act, 1872, and when any part of such statement is so used, any part thereof may also be used in the reexamination of such witness, but for the purpose only of explaining any matter referred to in his cross-examination.

The situation in Singapore is drastically different. Section 26 of our Evidence Act states:

Subject to any express provision in any written law, no confession made by any person whilst he is in the custody of a police officer, unless it is made in the 
immediate presence of a Magistrate, shall be proved as against such person.

The qualification 'subject to any express provision in any written law' is significant. It allows for the provisions of the present s. 122(5) of our Criminal Procedure Code, a widely drafted provision. Essentially, s. 122(5) makes any voluntary statement made by an accused at any time to, or in the hearing of, a police officer of the rank of sergeant and above admissible in evidence, on which the court trying the accused can act. There is no Indian equivalent of s. 122(5).

Having regard to all the reasons given above, we would stress that the Indian authorities on the interpretation of s. 30 were, in our view, not relevant to the Singapore context, because these authorities were decided against the backdrop of an Evidence Act differing in material aspects from ours.”

In a recent case of $P P v$. Dato Seri Anwar Ibrahim, ${ }^{53}$ Justice Arifin Jaka followed this liberal stand taken by the Singapore Court in Chin Seow Noi v. P.P. ${ }^{54}$ The learned judge said that an accused can be convicted solely on the confession of a co-accused, provided the evidence emanating from the confession satisfies the court beyond reasonable doubt of the accused's guilt. The learned judge felt "inclined to adopt and follow the interpretation of section 30 by the Singapore Court of Appeal, as I am of the same view with the learned author that it must be recognized that there is a difference in the provisions in respect of the definition of the word 'evidence' in section 3 between the Indian Evidence Act and our Act. As a result I conclude that a confession by an accused is capable of standing on its own and can be used against a co-accused to support a conviction provided the evidence emanating from the confession satisfies the court beyond doubt of the accused's guilt. The confession of Sukma can therefore be used standing own its own against Dato Seri Anwar.”

\footnotetext{
53 [2001] 3 MLJ 193 at pp. 265-266.

$54 \quad$ Followed in Lee Yuan Kwang \& Ors v P.P. [1995] 2 SLR 349 CA; PP v Rozman bin Jusoh [1995] 3 SLR 317.
} 
Similar sentiment was expressed by Augustine Paul in Norliana bt Sulaiman $v$ P.P. ${ }^{55}$

\section{CONCLUSION}

The Court of Appeal in Chin Seow Noi v. P.P. gave four reasons for elevating the evidential value of an accused's confession implicating his co-accused by giving section 30 a liberal interpretation.

(1) The Indian Evidence Act does not have a section like the Singapore Evidence Act section 17(2) defining the word confession.

(2) That in the Indian Evidence Act - the term 'evidence' is preceded by the words 'means and includes,' and therefore make the definition both explanatory and exhaustive. On the other hand in the Singapore Evidence Act "evidence" is preceded by the words "includes" in marked contrast to the Indian Evidence Act thus means in Singapore this meaning of 'evidence' is extensive.

(3) There is a marked difference between section 133 of the Indian Evidence Act that "An accomplice shall be a competent witness against an accused person; and a conviction is not illegal merely because it proceeds upon the uncorroborated testimony of an accomplice.

Illustration (b) to section 114 of Indian Evidence Act also says: "The court may presume that an accomplice is unworthy of credit unless he is corroborated in material particulars" and the Singapore Evidence Act section 135 which reads: "An accomplice is a competent witness against an accused person; and any rule of law or practice whereby at a trial it is obligatory for the court to warn itself about convicting the accused on the uncorroborated to testimony of an accomplice is hereby abrogated. 
(4) The inclusion of the words "subject to any express provision in any written law" in section 26 of the Singapore Evidence Act, which are absent in the Indian counterpart legislation makes the law drastically different.

It will be noticed that the first three differences between the Singapore and Indian legislations apply to the Malaysian counterpart legislation as well.

This perhaps would have persuaded Justice Augustine Paul in Dato Seri Anwar Ibrahim to invest section 30 of the Evidence Act with a higher status than has hitherto been the case.

It will be noteworthy to remember, that despite the fact that the Sri Lankan Evidence Ordinance has a definition of a confession - in section 17(2) like the Malaysian and Singaporean counterparts, section 30 of the Ordinance says that a confession of an accused implicating the co-accused shall not be taken into consideration.

This is clearly illustrated in an earlier reported case of Joseph $v$. Peris ${ }^{56}$ where the complainant charged two accused with theft of certain articles. The first accused was convicted inter-alia on the ground that the second accused made a statement to a District engineer implicating the first accused. The Supreme Court held that this statement was inadmissible in evidence against the first accused under section 30 .

It is submitted that admission as evidence a confession of an accused implicating a co-accused, is indeed a radical departure from the norms of justice allowing the worst form of hearsay to be admitted against another to his extreme prejudice. Accordingly it should be given the strict rather than the liberal construction.

The strict approach is also evidenced from the most recent case decided by the Court of Appeal, Teong Lung Chiong \& Ors. v. PP ${ }^{57}$ where at p. 175, Mohd. Noor Ahmad JCA chose to follow the strict interpretation of section 30 given by the Federal Court in Herchun Singh \& Ors. v. PP. ${ }^{58}$ Similarly the Court of Appeal in Lawrence B Masuni @

(1923) 24 NLR 485.

57 [2010]4 CLJ 1.

$58 \quad$ [1969] 2 MLJ 209 at p. 210.
} 
Fairus Bin Abdullah \& Anor v P.P. ${ }^{59}$ had held that the strict interpretation ought to be applied.

It is submitted the strict approach is also the preferred stand taken by the modern English criminal law as clearly propounded in $R v$ Hayter. ${ }^{60}$ 